\title{
HUMANISTIC INFORMATION STUDIES: A PROPOSAL. PART 2: NORMATIVE PROFESSIONALIZATION
}

\author{
Harry Kunneman \\ University of Humanistic Studies, Utrecht \\ Email: kunneman.h@gmail.com
}

\begin{abstract}
Beginning from a preliminary explanation in Part 1 (Logeion, v.1, n.2) about the transitional zone between system and world of life, this paper discusses the enrichment of the production of informational knowledge, focusing on the crucial role of normative professionalization and organizational cultures in Humanistic Information Studies. The concept of normative professionalization, initially constructed from Habermas analysis of 'system' and 'world of life', and Foucault's analysis of 'truth' and power in the social sciences, was enriched by the dialog with Freidson about "good works", Ricoeur's ethical perspective, the ethics of craftsmanship developed by Sennett, and Schön's analysis of professional reflexivity. Today it is possible to view the initially referred to transitional zone as a dynamic place where contemporary organizational theory and normative professionalization may open perspectives to wider moral values. Great conceptual efforts are needed. But the greatest challenge lies in the normative aspects which require new forms of cooperation based on radical equality between academic researchers and professionals working in organizations to connect the different forms of knowledge on the basis of equality, and characteristics established on the practice-based character of normative professionalization.
\end{abstract}

Key words: Humanistic Information Studies. Normative Professionalization. Organizational Theory.

\section{ESTUDOS HUMANÍSTICOS DA INFORMAÇAO: UMA PROPOSTA. PARTE 2: A PROFISSIONALIZAÇÃO NORMATIVA}

\section{Resumo}

Partindo do entendimento de uma zona de transição entre sistema e mundo da vida, apresentado na Parte 1 (Logeion, v.1, n.2), este texto discute o enriquecimento da produção de conhecimento informacional, enfocando o papel crucial da profissionalização normativa e das culturas organizacionais nos Estudos Humanísticos da Informação. O conceito de profissionalização normativa, inicialmente construído a partir da análise de 'sistema' e 'mundo da vida' de Habermas e da análise de Foucault sobre a relação entre verdade e poder nas ciências sociais, foi enriquecido pelo diálogo com Freidson sobre o "bom trabalho", a perspectiva ética de Ricoeur, a ética do artesanato desenvolvida por Sennett, e a análise da reflexividade profissional de Schön. Hoje podemos ver referida zona de transição inicial como um lugar dinâmico, onde a teoria organizacional contemporânea e a profissionalização normativa podem abrir a perspectiva de valores morais mais amplos. São ainda necessários grandes esforços conceituais. O maior desafio reside no lado normativo, que pede novas formas de cooperação com base na igualdade radical entre pesquisadores acadêmicos e profissionais que trabalham em organizações, para conectar as diferentes formas de conhecimento sobre uma base da igualdade e nas características, situadas e baseadas na prática, da profissionalização normativa.

Palavras-chave: Estudos humanísticos da Informação. Profissionalização normativa. Teorias organizacionais. 


\section{Introduction}

In the first part of this paper (KUNNEMAN, 2015b) I have proposed a preliminary definition of Humanistic Information Studies. In my rendering of HIS, this interdisciplinary endeavor aims to connect the descriptive and explanatory study of the informational dynamic traversing present-day societies with critical reflection on the ethical, moral and political questions internally connected with this dynamic. I have elaborated this preliminary definition along two complementary lines: sociological and epistemological. Building on Habermas' well known distinction between 'system' and 'life world' (HABERMAS, 1987), I have proposed to enrich and modify the binary opposition between system and life world by distinguishing a zone of interference situated in-between system and life world. This transitional zone is populated by organizations and professionals confronted with the necessity to develop situational combinations between the strategic 'logic' of the systems and the communicative logic of the life world. These combinations take the form of dynamically shifting, situational determined foreground-background relations between these logics. This spatial perspective on the complex interactions between systems and life worlds illuminates the pivotal role played by professionals and by organizational cultures in the actual, situational determined outcome of the permanent interference between systems and life worlds. Moreover it allows to connect the sociological analysis of this interference with a critical epistemological analysis of the crucial role of knowledge and its ongoing production and validation in the zone of interference between systems and life worlds. This connection between a critical sociological and a critical epistemological perspective is of decisive importance for Humanistic Information Studies, in view of its aim to combine the descriptive and explanatory study of the informational dynamic with critical reflection on the ethical, moral and political questions connected with this dynamic.

In the first part of this paper, I have tried to clarify the entanglement of sociological and epistemological questions flowing from this aim with the help of the distinction between three modes of knowledge production combined in HIS:

- Mode 1: academic, discipline-bound knowledge, characterized by relatively independent 'internal' agenda-setting within scientific communities

- Mode 2: all forms of scientific and technological knowledge-production that aim to provide solutions for practical problems, defined in complex processes of strategic, economic and political interaction between different stakeholders 
- Mode 3: ethical and moral resources and insights articulated and contained in organizational and professional traditions and brought to bear by professionals on the actual development of Mode 1 and Mode 2 knowledge and their many combinations, against the horizon of more just institutional arrangements.

Along these lines I have tried to flesh out my preliminary definition of Humanistic Information Studies, by situating HIS in the transitional zone between systems and life worlds and by further specifying its aim as the enrichment of the production of informational knowledge according to Mode 1 and Mode 2, with Mode 3 knowledge. In the second part of this paper, I want to clarify the nature of this enrichment by focusing on the crucial role of normative professionalization and organizational cultures in connecting the different forms of knowledge production at stake in HIS. This focus on normative professionalization and organizational cultures is motivated also by my worries and hopes with regard to the future of humanism and humanistic values. As I argued in the conclusion of the first part of this paper, the informational dynamic pervading our world society provides a prime example of the dramatic change in the 'sites' or 'places' where humanism and humanistic values can flourish. "Instead of the life world, the arts and academic philosophy as the privileged 'sites' for the articulation and transfer of humanistic values, the zone of transition between system and life world has become the most important site where humanistic values can and have to flourish" (KUNNEMAN, 2015b, p.22).

In the remainder of this paper I will elaborate in two steps the core idea of normative professionalization and its importance for the contribution of HIS to a more humane society. I start with a short historical sketch of the history of this idea and its development at the University of Humanistic Studies, where I have been working for the past 25 years. This historical sketch has two main aims. On the one hand it provides an introduction to the institutional and conceptual backgrounds of the idea of normative professionalization and its gradual development as an interdisciplinary, practice-oriented perspective. On the other hand it aims to illuminate one of the defining characteristics of normative professionalization: its constitutive connection with the life stories of concrete, embodied individuals and the normative questions confronting them in the organizational dynamics of their professional life. My sketch of the development of the idea of normative professionalization and its importance for HIS, cannot be separated from my own professional development as a teacher and researcher at the University of Humanistic studies and from the hopes, deceptions and slowly evolving insights connected with this development. Against the background of this 
historical sketch of the conceptual resources brought together in the theory and practice of normative professionalization, I will return in a second step to Humanistic Information Studies, in particular the importance of networks and flows in informational societies and the concomitant entanglement of systems and life worlds. In conclusion I will elaborate how normative professionalization as an ongoing reflexive process can contribute to the combination of the three forms of knowledge production constitutive for HIS and indicate some lines for the further development of HIS in view of securing a place for humanistic values not in opposition to, but as a vital part of the informational dynamic.

\section{A short history of Normative Professionalization as a critical perspective}

With the benefit of hindsight, the history of Normative Professionalization as an interdisciplinary, practice oriented perspective, can be divided in three phases (VAN EWIJK; KUNNEMAN, 2013, p. 10-14).

a) The first phase started around 1991 at the University of Humanistic Studies in Utrecht, the Netherlands, in an interdisciplinary research project composed of researchers from the social sciences and the humanities working on conceptual and practical questions in the domains of care, welfare and counseling. In the first phase of our research, attention was focused primarily on clarifying the normative content of professional knowledge and professional action, in particular the ethical quality of the relation between professionals and their clients. Our endeavor to clarify and understand the normative content of professional action in philosophical, epistemological and ethical terms had a strong critical import. It was meant as a conceptual and practical anti-dote against the increasing dominance of instrumental and technocratic forms of professionalism within healthcare, social work and education. We tried to articulate this normative content along two complementary lines. On the one hand the inherent normativity of professional knowledge and professional action was conceptualized with the help of Habermas' analysis of the opposition between the 'system' and the 'lifeworld', enriched with Foucault's critical analysis of the inner connection between 'truth' and power in the social sciences. On the other hand this inherent normativity was understood in terms of the personal ethical and moral commitment of professionals to deliver 'good work' and really relate to the needs and worries of patients, clients and students, as explicated among others in the 'ethics of care'. The concept of 'normative professionalism' as it was developed in the first phase thus foregrounded the normative frameworks necessarily 
brought into play by all forms of professional action and focused on the ethical and moral tensions and oppositions connected with this normative content, especially the opposition between economic and bureaucratic systems on the one hand and the ethical and moral resources of the everyday life world on the other hand.

b) In the second phase of research on normative professionalism, that started roughly around 2005, an important step forward was taken with the introduction of the idea of 'normative professionalization' as an ongoing reflexive process with regard to the normative content of professional action. Normative professionalism was now reframed as a descriptive concept, foregrounding the influence of normative frameworks and normative choices on all forms of professional knowledge. Normative professionalization could then be defined as the active process of developing and sustaining a critical and reflexive attitude towards the normative content of professional knowledge and professional action, against the moral horizon of wider social and political values. This definition resonated up to a point with Freidson's influential definition of professionalism as entailing

[...] commitment to a particular body of knowledge and skill both for its own sake and for the use to which it is put - that is to say, commitment to preserve, refine, and elaborate that knowledge and skill, to do good work, and, where is has application to worldly problems, to perform it well for the benefit of others - to do Good Works. (FREIDSON, 1994, p. 210)

Freidson seems to suggest however that the development and fruition of this ethical 'logic of professionalism' in the context of massive economic and bureaucratic pressure can be safeguarded by somehow insulating professional values and professional action from these pressures. Over and against this 'insulating strategy' our research in the second phase focused on possibilities for influencing and modifying these economic and bureaucratic pressures themselves, by furthering normative professionalization in organizational contexts in the zones of transition or 'zone of interference' between systems and life-worlds (KUNNEMAN, 1996, 2005; WIERDSMA, 2001). We could thus situate professional action in health care, social work and education within these in-between domains and understand The normative content of professional action in terms of the permanent interference of the logic of economic production and bureaucratic organization on the one hand and the dialogical logic of communicative action an reaching shared understanding on the other hand. This allowed us to understand the tensions and conflicts between these two 'logics' also in a positive sense, as a possible source of resistance to situational forms of dehumanization, but also as an impulse 
for the critical and reflexive development of new, morally responsable forms of professional action (KUNNEMAN, 2005, 2010A; JACOBS et al. 2007; VAN DEN ENDE; KUNNEMAN, 2008; VAN DEN ENDE, 2009; VAN EWIJK, 2010).

c) Our framework for the theory and practice of normative professionaliation has been strengthened in the third phase, roughly starting around 2010, in three dimensions: ethical, epistemological and organizational.

The ethical framework of normative professionalization, which originally was based primarily on Habermas' analysis of communicative action and rational argumentation, was enriched in the first phase with the help of different ethical perspectives. The first perspective which we have integrated into the ethical framework of normative professionalization, was based on the work of Paul Ricoeur, in particular his ethical analysis of narrative identities and moral commitments (KUNNEMAN, 2013a, 2015a; LEEUW, 2013). The subtle ethical and moral vocabulary provided by Ricoeur, especially his distinction between the 'idem' and the ‘ipse’ pole of personal identities, helped to articulate more clearly one of the central tenets of normative professionalization: the strong influence of personal ethical and moral perspectives and resources of professionals on the normative content and the ethical import of their work. Ricoeur's ethical perspective not only helped us to conceptualize the development of these ethical and moral resources by way of the interplay between the 'idem' and the 'ipse' pole of identity. Moreover it allowed us to articulate more clearly the relation between personal ethical commitments regarding the content of a good life on the one hand and moral values with regard to the just distribution of necessary resources for a good life on the other hand. In the conclusion of this paper I will come back to this crucial distinction and its importance for conceptualizing the moral quations connected with the very unequal distribution in present day societies of acces to information and influence on its content, storageoplossingen and circulation. For the moment I want to underline that the integration of Ricoeur's ethical perspective into the normative framework of normative professionalization, allowed us to expand Ricoeur's famous formula that sums up his ethical perspective - "a good life with and for others in just institutions” (RICOEUR, 1981). In our critical humanistic rendering this formula is expanded as "a good meaningful life based on good work with and for others in just institutions.”

A second perspective that has strengthened the conceptual framework of normative professionalization in the ethical dimension was provided by Frans de Waal's work on the 
ethical and moral continuities between apes and humans. His analysis of the deep evolutionary roots of empathy and care, resonates strongly with Ricoeur's analysis of solicitude (WAAL, 2009, 2013). But his analysis also provided us with a deeper understanding of the complexity and the conflictual character of the basic architecture of human emotions: both 'Chimpansee and 'Bonobo'. This perspective was of great help in correcting the lack of attention in Paul Ricoeur's ethics for the pervasive influence of power relations and the deep emotional roots of domination and submission (KUNNEMAN, 2013a).

A third perspective that has strengthened the conceptual framework of normative professionalization in the ethical dimension was provided by Richard Sennett's work on craftsmanship and cooperation, which we combined with Donald Schön's well-known analysis of professional reflexivity (SENNETT, 2008, 2012, SCHÖN, 1983). In the first phase of the research on normative professionalism, attention was focused almost exclusively on the domains of healthcare, social work and education. As a consequence research into normative professionalism foregrounded the relational character of the ethical commitments of professionals in these domains, in combination with the moral import and the wider social significance of caring, helping and educating as organized professional activities. Due to this focus, the content or 'materiality' of professional work tended to fade into the background. Sennett's work on craftsmanship was very important in bringing this specific content into the foreground and helped us to focus research on normative professionalization also on the specific 'materiality' at stake in different professions. His analysis of the 'resistance' offered by the specific 'material' professionals work with and the necessity to develop a dialogical relation with this material, were of great help in articulating the 'ethics of craftsmanship' as a powerful component of and resource for normative professionalization (KUNNEMAN, 2012). Sennett's analysis of the importance of 'dedicated craftsmanship' proved to combine very well with Donald Schön's classical analysis of professional reflexivity, that had served already as an important conceptual resource in the first phase of our research on normative professionalism (SCHÖN, 1991). Schön introduced the influential distinction between the 'high grounds' where professionals can avail of proven knowledge and techniques, and the 'swampy lowlands' where 'proven' knowledge fails to provide an adequate understanding of the 'messy' problems that face them here. In order to deal adequately with the complex problems confronting them here, professionals have to accept uncertainty, undertake experiments and recast their self-evident professional framework on the basis of 'reflection in action'. With the help of the distinction between the high grounds and the swampy lowlands, 
Schön explicitly addresses the ethical and moral dimension of professional knowledge and professional action. As he says: “[...] in the swamp are the problems of the greatest human concern.” In the confrontation with 'messy' problems the ethical resources of professionals are of prime importance (SCHÖN, 1983, p. 42-43).

By combining Ricoeur's ethical perspective with Sennett's view of craftsmanship and Schön's analysis of professional reflexivity, we could considerably enrich our 'vocabulary' for the clarification of the inherent normativity of professional knowledge and professional action and further clarify the decisive role of the ethical and moral resources professionals avail of: their courage (or lack of it), their dedication to tackle instead of avoid 'problems of great human concern'; their ability to stand the uncertainty and the messiness of these problems and last but not least their dedication to ‘dialogical craftsmanship' (VAN DEN ENDE, 2010; NAP, 2012; VAN EWIJK; KUNNEMAN, 2013).

In close interaction with this conceptual progress in the ethical dimension, we have also strengthened the conceptual framework of normative professionalization in the epistemological dimension. An important and very fruitful resource in this respect was provided by critical complexity thinking, as originally developed by Edgar Morin and extended in particular by Paul Cilliers and Mario Giampietro. To start with, the concepts and ideas developed within critical complexity thinking helped to articulate more clearly the interplay of epistemological and ethical questions on the level of professional knowledge and professional action. As transpires from their research, complex systems confront us with the inherent limitations of any model of their characteristics, because complex systems always allow for different, non-equivalent, but potentially equally valid models. According to Cilliers the modeling of complex systems thus necessarily involves normative choices. "Normative issues are intertwined with our very understanding of complexity” (CILLIERS, 2005, p. 264).

These normative issues are moreover inseparable from questions of power. As Giampietro states in the context of a critique of reductionist epistemologies: "[...] reductionist science works well in all cases where power is effective for ignoring or suppressing legitimate but contrasting views on the validity of the pre-analytical problem structuring within the population of users of scientific information.” (GIAMPIETRO, 2004, p. 26) This perspective allowed us to articulate the normative content of professional knowledge and professional action in terms of the interplay between epistemological and ethical complexity (PIETERS, 2010; CILLIERS, 2013, KUNNEMAN, 2013a). 
This brings me to the third dimension in which the conceptual framework of normative professionalization has been strengthened during the past five years. This dimension concerns the organizational dimension of professional action. To start with, we have reinterpreted the static spatial metaphor of a zone of interference between the domains of system and life-world in temporal and dynamic terms, as briefly referred to already above. Building on the work of critical complexity thinkers we have interpreted this interference as a dynamic, both constrained and open process, characterized by conflicting attractors and shifting constraints, resulting in emergent, situation-specific outcomes (CILLIERS 1998; MORIN, 2008; GIAMPIETRO, 2004; KUNNEMAN, 2013a). When the interference between 'system' and 'life-world' is conceptualized in terms of the dynamic interplay of a plurality of conflicting 'attractors' and constraints that operate at various levels and time-scales, the static idea of a 'logic' characterizing these 'domains' can be reinterpreted in a dynamic way. The unavailable interference between 'system' and 'life world' can now be understood in terms of divergent attractors operating with different intensity (or 'force') in all organizational interactions. At specific moments in professional practice - designated by van den Ende as 'kantelmomenten' or 'turning moments' - reflective insights by professionals can contribute to an unexpected shift or even turnabout in the relation between 'systemic' and 'communicative' attractors (VAN DEN ENDE; KUNNEMAN, 2008; VAN DEN ENDE, 2011; KUNNEMAN, 2012).

This dynamic reinterpretation was further strengthened by the close connection that has developed in the course of the project between the theory of normative professionalization on the one hand and insights from contemporary organizational theory on the other hand. This connection benefited from the shift that has taken place during the past decade in organizational theory from vertical, top-down perspectives focusing on transparency, control and maximizing efficiency, to more horizontal perspectives, oriented towards sense making and cooperation and focusing on the realization of organizational goals on the basis of shared meaning, co-creation and reflexive learning (TSOUKAS, 2005). André Wierdsma refers in this context to "co-creation of change, based on respect for differences, 'temporarily workable agreements, and stepping into - instead of avoiding - 'spots of difficulty' (WIERDSMA, 2001; WIERSDMA; SWIERINGA, 2011).

This critical organizational perspective fitted well together with core notions from the theory of normative professionalization, in particular the necessity to get into the 'swampy 
lowlands' and develop a reflective relation there towards problems of cooperation and craftsmanship against the horizon of wider moral values.

\section{Practical anchors}

The development of this conceptual framework was stimulated not only by 'conceptual input' but also and even foremost by our practice-oriented research on normative professionalization in domains such as healthcare, social work, education, the police force, organizational development and corporate social responsibility. Together with the conceptual innovations that emerged in our research, this research into factual processes of normative professionalization provides the scientific backbone of this research program. Most of the practice-oriented research undertaken during the past five years is done by 'reflexive professionals' from a broad range of social domains, concerned about normative and moral issues in their own fields. Between 2009 and 2014, twenty-four PhD projects were started within the research cluster 'Normative Professionalization' in the Graduate School of the University of Humanistic Studies, spread over a broad range of professional fields and social domains. Most of these projects combine conceptual questions with qualitative research. These PhD-projects have considerably enriched and fortified both the empirical roots and the social relevance of our research. A good example of this enrichment is provided by the dissertation of Jan Nap on normative professionalization in the Dutch police force (NAP, 2013). Using qualitative and narrative research methods, Nap has elicited a series of practical reflections from 'street cops' on concrete examples of 'good' and 'not so good' police work coming from their own daily practice. His description of these examples together with his own comments, have served as a basis for reflection in small groups of police officers on the moral horizon of good police work. Moreover they have been used by Nap to underline the great distance between the practical reality of day to day police work at the micro-level on the one hand, and the bureaucratic reality of the ever changing control 'schemes' at the level of the police top on the other hand. Referring to insights from critical organizational studies, Nap has moreover used his findings for recommendations for new, more horizontal forms of police leadership that have contributed to broader discussions in the Dutch police force on the influence of dominant organizational cultures and avenues to enrich these in a moral sense. 


\section{The increasing entanglement of systems and life worlds}

As transpires from this short description of the development of normative professionalization, the conceptual framework underlying this concept connects different disciplines, in particular philosophy, ethics, sociology, psychology and organizational theory. It thus has a strong interdisciplinary character and touches upon a wide range of scientific debates. It combines this interdisciplinary character with a trans-disciplinary dynamic, connecting scientific insights with problems and challenges in professional contexts, in view of supporting and enriching professional reflexivity and horizontal organizational developments in a broad range of scientific, technological and social domains. In this paragraph I want to elaborate how normative professionalization as an ongoing reflexive process can contribute to the combination of the three forms of knowledge production constitutive for HIS and open up new possibilities for political action.

According to the preliminary definition proposed above, HIS combines descriptive and normative analyses of the informational dynamic traversing and transforming present day world society. The descriptive side of this endeavor confronts HIS with the formidable challenge of doing conceptual justice to the complexity of this dynamic. Even greater however is the challenge posed by the normative side. Here, with regard to normative questions, HIS not only run the risk concealing partisan standpoints under the cloak of scientific respectability, but also the converse risk of dodging the ethical and moral questions connected with the pre-analytical choices underlying scientific theories and technological designs (GIAMPIETRO C.S., 2012).

The conceptual framework of normative professionalization sketched above, allows to tackle the normative questions connected with these risks with the help of a complex view on the relation between knowledge and values that points beyond the traditional opposition between objective knowledge and subjective values. By defining HIS in terms of the combination of different modes of knowledge and further specifying this combination as an ongoing reflexive process of normative professionalization, the real and unavoidable risk of partisanship in the realm of science can be confronted on a different, more promising and basis then the vain effort to purify science from all normative elements. The risk of normative prejudices and partisan analyses can now be redefined in terms of un-reflexive and un-critical forms of normative professionalism, characterized by the concealment of the normative choices connected with all forms of Mode 2 science behind the facade of 'objective' Mode 
one knowledge. Moreover, confronting this risk - and the converse risk of dodging the ethical an moral responsibility for pre-analytical choices in scientific research - can now be envisaged in terms of creating space for normative professionalization as an ongoing reflexive process with regard to situation-specific combinations of different forms of knowledge and in terms of strengthening cultural resources in organizations and professions that further and enrich this reflexive process.

At this point the connections between the epistemological, sociological and ethical strands in my proposal for the further development of HIS come into view. Seen from a sociological viewpoint, normative professionalization is at stake in the zones of transition between systems and life worlds, where their different 'logics' come together and intersect in varying foreground - background relations. It is of crucial importance for the conceptual architecture of HIS to understand that there is more at stake here then a collision between the communicative logic of speech and speech-acts, and the reductive logic of markets and bureaucracies, as analyzed by Habermas. What is missing is this picture is precisely the crucial role of scientifically trained professionals, actively constructing Mode two knowledge and shaping specific technologies and forms of government in the interference between 'systems' and 'lifeworlds' as analyzed by Habermas (1987, 2001).

In his recent novel In the light of what we know, Zia Raider Rahman provides an illuminating characterization of the traditional 'intelligentsia', as perceived through the eyes of one of the main characters of this impressive novel: “..the middle classes - that is the intelligentsia, the writers, academics, doctors and lawyers, and all those whose labour is framed by the transmission of words, written or spoken, but only after years of study - to me these people were forbidding in the particular power they held. They seemed to have a natural, ordained intimacy with what I loved, the world where I was safe, the world of imagination, books and ideas.” (RAHMAN, 2014, p. 46). This image of the intelligentsia and their particular power provides an apt articulation of the traditional humanistic values, that in the final analysis also underlie Habermas' analysis of speech, argumentation and rational consensus. These values are essentially connected with speech and the ideas and insights communicated with the help of words, spoken or written. The specific form of authority connected with these values is connected with the promise of transcendending power, by way of consensual forms of action-coordination, instead of strategic forms of influencing others. It is this horizon of open dialogue, under the sign of rational argumentation free of distorting 
power relations, which is brought to bear by Habermas against the colonization of the lifeworld by the systems (HABERMAS, 1983, 1987).

As suggested above, the conceptual and political strategy underlying such a defense of humanistic values rooted in words and books, has only a limited significance in present day informational societies. Nowadays, words and books have not only been augmented - and even partially superseded - by streams of digitalized information and by the visual conveyance of meaning and values. This development has moreover structurally altered the speed, density and content of communications, both in systems and in life worlds. In our times, (economic and political) systems have become 'networked systems'. The world-wide network of financial institutions such as commercial banks, stock exchanges and national and international governmental agencies, and the dense streams of real time financial information flowing between them, provides a vivid illustration of the new, networked architecture of present day economic systems and their interconnection with political systems. Moreover, a great part of present day life worlds have become 'networked life worlds', in which the communicative coordination of action plans and actions is increasingly dependent on and regulated by digitalized channels and flows of information, not only verbal but increasingly also visual. The networked character of present day life worlds is vividly illustrated by the new social media and by all the physical and mobile networks that enable the new 'virtual' social links and channel all the streams of information, images and entertainment that pervade 'networked life worlds' all over the globe.

This new, informational and 'networked' architecture of systems and life worlds alike is internally connected with the progressive extension and multiplication of zones of transition between systems and life-worlds, up to a point where there different logics have become so entangled that in many instances they can hardly be separated from each other. The 'likes' for instance that are 'awarded' to posts, blogs or to sites by readers or visitors, can be interpreted as a 'consensual' affirmation of worth, if need be backed up by arguments. But in many cases they also seem the result of a generalized 'Matthew Effect', as analyzed by Robert Merton with regard to the popularity of famous scientists, further enhanced by the active soliciting of 'likes' by companies and organizations (MERTON, 1968). As a result, the informational content of a specific number of 'likes', or of a specific position in ranking lists, is inherently and irredeemably 'mixed up'. The same goes up to a point for the heart of the political process in democratic societies: the election of governments on the basis of the number of votes for candidates of political parties. Here also the motives underlying votes can be seen as 
a mixture of, on the one hand, a conscious choice that could be backed up by arguments and rational deliberation in the Habermassian sense and, on the other hand, the whole process of 'marketing' and framing candidates, especially in the new media, and all the concomitant 'spinning' of information and the 'image-building' of candidates. A different but equally important illustration of the increasing entanglement of the logics of systems and life worlds is provided by the dominant role of scientifically validated knowledge and information in the governance of citizens in modernized societies. Not only within state bureaucracies, but even more so in domains formerly dominated by communicatively articulated moral values, in particular education and health care. An interesting example of the entanglement of scientific knowledge and information on the one hand and moral standards with regard to 'normal' behavior in the classroom on the other hand, is provided by the diagnosis of ADHD ('attention deficit hyperactivity disorder') to a rapidly increasing number of children in primary education. Teachers and parents alike receive all kinds of information on the 'ins and outs' of ADHD that further and legitimize attaching the new label of ADHD to the 'unruly' conduct of specific children and administer Ritalin to them as an effective treatment of this 'disorder'. This information and its practical influence provide a prime example of Mode 2 knowledge in which the results of scientific research, interests of pharmaceutical companies and pedagogical advisers and moral values with regard to proper behavior in classrooms are completely mixed up and can hardly be separated from each other. The educational process in primary schools thus appears as a specific zone of transition between 'system' and 'life world' where their different logics have become entangled.

Seen from an 'orthodox' Habermassian perspective, the progressive extension of such entangled, 'mixed up' forms of communication in present day informational societies, signals a worrisome intensification of the 'colonization' of the life world and a concomitant diminishment of possibilities for rational deliberation and of normative control of economic and political systems based on communicatively validated values. Seen from the perspective sketched above, the problem with such a diagnosis is not only that this 'colonization' is welcomed so enthusiastically by most of the citizens and consumers involved. Equally problematic is the fact that the 'crises' predicted by Habermas more then thirty years ago as a result of the colonization of the life world - the loss of meaning, the weakening of identities and the undermining of solidarity - have not materialized. In most modernized countries, the entanglement of systems and life worlds has become the normal condition of a good life for the majority of citizens. Seen in this light, the diagnosis of impending crises structurally 
undermining the communicative reproduction of the life world can only be upheld by somehow reviving the old Marxist idea of a false consciousness at the side of the majority of citizens. That seems too high a price to pay, both conceptually and politically.

\section{Into the messiness}

Seen from the perspective developed here, the increasing entanglement of systems and life worlds does not necessarily imply the undermining of humanistic values and the loss of possibilities for political action inspired by such values. On the contrary, it opens up new possibilities for political action, based on 'working in and with' the complexity connected with this entanglement, instead of trying to separate the different components 'from the outside', on the basis of universal, decontextualized criteria. It is clear however that accepting the entanglement of systems and life worlds and the necessity to work in and with the concomitant complexity, signals a far reaching shift in the most important locus where humanistic values can flourish and in the form of political action guided by such values. The key for understanding this shift - and for making proper use of the new political possibilities connected with it - is provided by the pivotal role played by knowledge, by professionals and by professional organizations in shaping the zones of transition where the entanglement of systems and life worlds is brought about on a 24/24 basis all around the globe. I have proposed to clarify this pivotal role (and the new political possibilities connected with it) by distinguishing between three different Modes of knowledge production and by introducing the perspective of normative professionalization as an ongoing reflexive process aiming for situational connections between the different Modes allowing to enrich the production and professional use of knowledge according to Mode 1 and Mode 2, with Mode 3 knowledge. To concretize this perspective, I will briefly indicate three provisional guidelines for enriching Mode 1 and Mode 2 knowledge with Mode 3 knowledge in concrete professional practices. These guidelines have emerged in the research of my PhD's and in my own professional experience in different settings. As I will argue in conclusion, these guidelines can also serve as signposts for the further development of Humanistic Information Studies. 


\section{Three provisional guidelines}

The first guideline concerns the decisive role of the life histories of professionals, in particular the development of their ethical and moral resources. Whereas in an orthodox Habermassian perspective, the whole domain of personal ethics is relegated to the private sphere, the perspective of normative professionalization foregrounds both the factual influence of the life stance of individual professionals on the content of their work and the importance of furthering reflexive insights that can help to enrich this influence in an ethical and moral sense. An integral part of the complexity of concrete forms of entanglement between the reductive logic of systems and the' communicative' logic of life worlds in different domains is precisely the modulation of this entanglement due to differences in the life stance of the professionals involved. A clear illustration of this modulation and its effects is provided by the way in which professionals deal with legal and bureaucratic rules and regulations, for example whether they apply them rigorously and decontextualizing, whether they make exceptions bases on favoritism, or whether they try to contextualize rules and regulations in the light of their moral import. Here, the ethical 'character' of the professionals involved - in the sense of Paul Ricoeur (1992) - and moral qualities such as courage, compassion and 'phronesis' (or their contraries), play a central role in shaping the concrete outcome of professional decisions and interventions. The same goes for the dedication (or the lack of it) of professionals to craftsmanship, as analyzed by Sennett (2008), in particular dedication to the unending process of developing one's craftsmanship by way of a dialogical relation with the specific 'material' at stake in one's profession. In both these respects - the ethical character and moral qualities of professionals and their dedication to craftsmanship the ethical and moral horizon orienting the effort to work in and with the complexity of concrete forms of entanglement, is provided by 'good work with and for others', to borrow and amend Ricoeur's felicitous phrase (1992, p. 180).

This brings me to the second provisional guideline for enriching Mode 1 and Mode 2 with Mode 3 knowledge in concrete professional contexts. This guideline is closely connected with the first one, but addresses a different level of the complexity of concrete forms of entanglement, viz. the culture of professional organizations. Within the vast literature within contemporary organization studies on this subject (SCHNEIDER; BARBERA, 2014), I focus on the role of narratives in organizational cultures and the articulation of organizational identities (CZARNIAWSKA, 1992; ENZ, 1988). Seen in the light of the foregoing analysis 
narratives provide the most important articulation of the complexity connected with the entanglement of systems and life worlds. Organizational narratives articulate the history and the identity of organizations and ant their members and sketch possible futures. They accomplish this in the form of a many-layered network of different entangled narratives, that is characterized by tensions and by open or covert conflicts on guiding values for their future development. As Paul Ricoeur repeatedly underlines, narratives are inherently normative. They contain (implicit or explicit) ethical and moral qualifications and disqualifications; they cover up or give voice to conflicts and power struggles; and they articulate inspiring or discouraging examples and moral hopes and fears with regard to the future development of organizations and their members. Narratives thus play a crucial role in the 'dimming' or 'lighting up' of the ethical and moral horizon of 'good work with and for others' in professional organizations. They can be dominated by the articulation of envy and disgust and contribute to cynicism and rigid dividing lines ('our management cannot be trusted'; 'our employees cling to the past and lack flexibility', etc.). They can impose one dominant 'master narrative' with regard to the identity and mission of organizations and be used to disqualify all alternative narratives. But they can also act as a source of moral encouragement and inspiration and create room for creative frictions between different articulations of the content of good work in specific situations.

The last provisional guideline I want to touch upon briefly, concerns the complex connections and feed-back loops between the development of the ethical and moral resources of individual professionals and the level of organizational narratives. As referred to already above, the perspective of normative professionalization has strongly benefited from Donald Schön's analysis of professional reflexivity, in particular his distinction between the 'high grounds' and the 'swampy lowlands' where 'proven' knowledge fails to provide an adequate understanding of the 'messy' problems that face professionals in the swamp. The complexity of the problems they encounter here, urges professionals to reframe taken-for-granted, but inadequate frameworks on the basis of cautious experiments and reflection in action (SCHÖN, 1983), and thus develop their craftsmanship. In the light of the unequal power relations characterizing 'ex hypothesi' the production of Mode 2 knowledge, and in view of the situational legitimation of the these power relations by organizational 'master narratives', the messiness confronted by professionals in the swampy lowlands appears to be much broader and more complex then Schön allows for. This messiness also involves the entanglement of the different 'logics' of systems and life worlds and the role of unequal 
power relations and suppressed conflicts in the construction and stabilization of 'high ground' knowledge in concrete organizational contexts and specific professions, in particular dressing up Mode 2 knowledge with the cloak of undisputed Mode 1 knowledge. Moreover, this messiness is also connected with all the misunderstandings, forms of 'othering', envy, vicious gossip, abuse of power and all the concomitant open and covert conflicts that emerge in the organizational entanglement of systems and life worlds and seriously hamper or even completely block possibilities for accomplishing 'good work with and for others'.

Broadening and complexifying Schön's analysis along these lines, illuminates the necessity to augment the reflection-in-action on the level of individual professionals with critical reflection between professionals on their relational dynamics and their own role in furthering or blocking good work with and for others. Creating space for such forms of critical reflection asks for mutual 'containment' in the sense of Jessica Benjamin (1998) and for worthy struggles', as Jan van Ewijk says (2013), not only between professionals themselves and between professionals and members of the management of organizations, but if need be also with clients and customers.

\section{By way of conclusion}

According to my proposed definition, Humanistic Information Studies aim to connect the descriptive and explanatory study of the informational dynamic traversing present-day societies with critical reflection on the ethical, moral and political questions internally connected with this dynamic. In my view, the greatest challenge confronting HIS (and comparable forms of critical study), do not lie on the critical side. To be sure, great conceptual efforts are needed to illuminate the daunting complexity to be found at the descriptive and explanatory side, and new forms of interdisciplinary cooperation have to be developed to accomplish this task. But there is a whole tradition of critical scientific enquiry that can support and orient this effort. The greatest challenge lies in my eyes at the normative side. My analysis suggests that influencing the informational dynamic under the sign of humanistic values, asks for new forms of cooperation based on radical equality between on the one hand academic researchers and on the other hand professionals working in organizations where the informational dynamic is actually produced on a day-to-day basis. This requirement flows directly from the aim to connect the different forms of knowledge on the basis of equality, and 
the situated, practice-based character of normative professionalization. As suggested already by the crucial role of professional and organizational reflexivity in the three provisional guidelines indicated above, the most promising route for furthering radical equality between academic researchers and professionals in the development of equal connections between the different forms of knowledge, is simply to further research skills at the side of professionals and support them in critically investigating their own professional context and use the results both for enriching professional and organizational reflexivity in their own domain and for publications in relevant scientific journals. In this way, HIS could come to stand on two, equally strong and cooperative legs and confront both the descriptive and normative challenges connected with the further development of HIS with confidence and inspiration.

\section{References}

BENJAMIN, Jessica. Shadow of the other: intersubjectivity and gender in pscychoanalysis. New York: Routlege, 1998.

CILLIERS, P. Complexity and relativism. Theory, Culture and Society, v. 22, n.5, p. 255267, 2005. Disponível em: <http://tcs.sagepub.com/content/22/5/255.abstract>. Acesso em: 14 set. 2015.

CILLIERS, P. Complexity \& postmodernism. London/New York: Routledge, 1998

CILLIERS, P. A crisis of knowledge: complexity, understanding and the problem of responsible action. In: DERKX, P.; KUNNEMAN, H. (Ed.). Genomics and democracy. Towards a 'lingua democratica" for the public debate on genomics. Amsterdam/New York: Rodopi, 2013, p. 37-60.

CSARNIAWSKA-JOERGES, B. Exploring complex organizations: a cultural perspective. Newbury Park (CA): Sage, 1992.

EWIJK, H. van. Maatschappelijk werk in een sociaal gevoelige tijd. Amsterdam: Humanistic Univ. Press / SWP Books, 2010.

EWIJK, H. van; KUNNEMAN, H. (Eds.). Praktijken van normatieve professionalisering. Amsterdam: SWP Books, 2013.

ENZ, C.A. The role of value congruity in intraorganizational power. Administrative Science Quarterly, v. 33, p. 284-304, 1988.

FREIDSON, E. Professionalism reborn: theory, prophecy and policy. Chicago: Univ. of Chicago Press, 1994. 
GIAMPIETRO, M.; MAYUMI, K.; SORMAN, A. The metabolic pattern of societies: where economists fall short. New York: Routledge, 2012.

GIAMPIETRO, M. Multi-scale integrated analysis of agroeco systems. London: CRC Press, 2004.

HABERMAS, J. Vorstudien und erganzungen zur theorie des kommunikativen handelns. Frankfurt: Suhrkamp Verlag, 1983.

HABERMAS, J. The critique of functionalist reason, v.2. In: The theory of communicative action. Boston: Beacon Press, 1978.

HABERMAS, J. The postnational constellation. Cambridge: MIT Press, 2001.

HABERMAS, J. A postsecular worldsociety? On the philosophical significance of postsecular consciouness and the multicultural world society. An interview with Jürgen Habermas, por Eduardo Mendieta, s.l., 2007. Disponível em: <http://blogs.ssrc.org/tif/wpcontent/uploads/2010/02/A-Postsecular-World-Society-TIF.pdf>. Acesso em 14 set. 2015.

JACOBS, G. C. et al. (Org.). Goed werk: verkenningen van normatieve professionaliserin. Amsterdam: SWP, 2007.

KUNNEMAN, H. P. (2010a). Ethical complexity. In: CILLIERS, P.; ALLEN. R. (Eds.). Complexity, difference and identity. Dordrecht: Springer verlag, 2010a, p. 131-164.

KUNNEMAN, H.P. (2013a). Ethical complexity, hermeneutics and mode 3 knowledge. In: DERKX, P.; KUNNEMAN.H. (Eds.). Genomics and democracy. Towards a 'lingua democratica" for the public debate on genomics. Amsterdam/New York: Rodopi, 2013a, p. 105-129.

KUNNEMAN, H.P. (Ed.). Good work: the ethics of craftsmanship. Amsterdam: SWP Books, 2012.

KUNNEMAN, H. P. Humanistic information studies: A proposal. Logeion, v.1, n.2, p. 5-22, mar./ago. 2015b. Disponível em: <http://revista.ibict.br/index.php/fiinf/article/view/2327>. Acesso em: 14 set. 2015.

KUNNEMAN, H. P. Kleine waarden en grote waarden. Normatieve professionalisering als politiek perspectief. Amsterdam: Humanistic University Press/SWP, $2013 \mathrm{~b}$.

KUNNEMAN, H. P. Normatieve professionaliteit: Een appel. Sociale Interventie, v. 5, n.3, p. 107-112, 1996.

KUNNEMAN, H. P. Social work as laboratory for normative professionalisation. Social Work \& Society, v. 3, n.2, p. 191-200, 2005.

KUNNEMAN, H.P. Viable alternatives for commercialized science: the case of humanistics. In: RADDER, H. (Ed.). The commodification of academic research. Science and the modern university. Pittsburgh: University of Pittsburgh Press, 2010b, p. 307-336. 
KUNNEMAN, H.P. The political importance of voluntary work. Foundations of Science, v. 20, n. 1, 2015a. Disponível em: <DOI 10.1007/s10699-014-9403-x>. Acesso em: 14 set. 2015.

KUNNEMAN, H. P. Trans-species peace making: Our evolutionary heritage. In: VERBEEK, P.; PETERS, B.A. (Eds.). Behavioral processes and systems of peace. Chichester (UK): John Wiley and Sons (no prelo).

LEEUW, Marc de. The unstable equilibrium: Paul Ricoeur's renewal of philosophical anthropology. 2013. Tese (doutorado em Filosofia)- Universidade de Estudos Humanísticos, Ultrecht, 2013. Disponível em:

$<$ http://repository.uvh.nl/bitstream/handle/11439/111/Proefschrift\%20Marc\%20de\%20Leeuw .pdf?sequence=1>. Acesso em: 14 set. 2015.

MERTON, R. The matthew effect in science. Science, v. 159, n. 3810, p. 56-63, 1968.

MORIN, E. On complexity. New York: Hampton Press, 2008.

NAP, J.A. Vragen naar goed politiewerk: belang-stellend ontwikkelen van alledaagse proaktik. Een proeve van normatieve professionalisering. 2014. Dissertação (mestrado em Filosofia)- Univrsidade de Estudos Humanísticos, Ultrecht, 2014

NAP, J. Vragen naar goed politiewerk: Belang-stellend ontwikkelen van de alledaagse praktijk. een proeve van normatieve professionalisering. Den Haag (Holanda): Boom-Lemma, 2012.

PIETERS, C. P. Into complexity: a pattern-oriented approach to stakeholders communications. Boca Raton (Florida): Dissertation.com, 2010.

RAHMAN, Z.R. In the light of what we know. New York:Macmillan,2014

RICOEUR, P. Oneself as another. Chicago: Univ. of Chicago Press, 1992.

RICOEUR, P. Hermeneutics and the Human Sciences: essays on language, action and interpretation. Edição e tradução de John B. Thompson. Cambridge: Cambridge Univ. Press, 1981.

SCHNEIDER, B.;BARBERA, K. (Eds.). The Oxford handbook of organizations climate and culture. Oxford: Oxford University Press, 2014.

SCHÖN, D. A. The reflective practitioner. How professionals think in action. New York: Basic Books, 1983.

SCHÖN, D. A. Educating the reflective practitioner: toward a new design for teaching and learning in the professions. Oxford/ San Francisco: Jossey-Bass, 1991.

SENNETT, R. The Craftsman. London: Penguin Books, 2008. 
SENNETT, R. Together: the rituals, pleasures and politics of cooperation. London: Penguin, 2012.

SWIERSTRA, J.;WIERDSMA, A. Lerend organiseren. 2. ed. Groningen: WoltersNoordhof, 2010.

TSOUKAS, H. Review of complex knowledge: studies in organizational epistemology. Oxford: Oxford Univ. Press, 2005

TSOUKAS, H.; KNUDSEN, C. (Eds.). The oxford handbook of organization-theory. Meta-theoretical perspectives. Oxford: Oxford University Press, 2003.

VAN DEN ENDE, T. M. L. Waarden aan het werk. Over kantelmomenten en normatieve complexiteit in het werk van professionals. Amsterdam: SWP Books, 2009.

VAN DEN ENDE, T. M. L. Waarden aan het werk: over kantelmomenten en normatieve wek van professionals. Amsterdam: SWP/ Humanistic Univ. Press, 2011.

VAN DEN ENDE, T. M. L.; KUNNEMAN, H. P. Normatieve professionaliteit en normatieve professionalisering een pleidooi voor conceptuele verdieping. In: JACOBS, G. et al (Eds.). Goed werk. verkenningen van normatieve professionalisering. Amsterdam: SWP, 2008, p. 68-87.

VAN EWIJK, J. Waardig strijden. In: EWIJK, H. van; KUNNEMAN, H. (Eds.). Praktijken van normatieve professionalisering. Amsterdam: SWP Books, 2013.

WAAL, F. de. The age of empathy. Nature's lessons for a kinder society. New York: Harmony Books, 2009.

WAAL, F. de. The bonobo and the atheist. In search of humanism among the primates. New York: W.W. Norton \& Company, 2013.

WIERDSMA, A.F.M. Leidinggeven aan co-creërend veranderen . Breukelen (Holanda): Nyenrode University Press, 2001.

WIERDSMA, A. F.M.; SWIERING, J. Lerend organiseren en veranderen. Groninger (Holanda): Noordhoof, 2011. 